CZASOPISMO INŻYNIERII LĄDOWEJ, ŚRODOWISKA I ARCHITEKTURY JOURNAL OF CIVIL ENGINEERING, ENVIRONMENT AND ARCHITECTURE

JCEEA, t. XXXIV, z. 64 (3/I/17), lipiec-wrzesień 2017, s. 67-80, DOI: 10.7862/rb.2017.104

Marta KADELA ${ }^{1}$

\title{
ZASTOSOWANIE PIANOBETONU W WARSTWACH KONSTRUKCJI NAWIERZCHNI DROGOWEJ
}

\begin{abstract}
Pianobeton jest klasyfikowany jako beton lekki, który powstał poprzez zamknięcie w zaczynie cementowym porów powietrza, utworzonych przy użyciu środka pianotwórczego. Chociaż sam pianobeton jest znany od około 100 lat, praktyczne jego zastosowanie dotychczas ograniczało się głównie jako materiału niekonstrukcyjnego. Przez wiele lat był stosowany jako materiał stosowany do wypełnienia wolnych przestrzeni przy ścianach oporowych, izolacja fundamentów, warstwa pod posadzką oraz jako izolacja akustyczna. Jednakże w ostatnich latach rośnie zainteresowanie pianobetonem jako materiałem konstrukcyjnym. W artykule przedstawiono zastosowanie pianobetonu $\mathrm{w}$ drogownictwie, ze szczególnym uwzględnieniem nawierzchni drogowych. Przedstawiono również wyniki badań laboratoryjnych oraz analiz numerycznych, stanowiących przesłankę do zastosowania pianobetonu w warstwie podbudowy pomocniczej nawierzchni drogowej. W ramach badań laboratoryjnych, mających na celu wyznaczenie właściwości fizycznych materiału przeprowadzono badania wytrzymałości na ściskanie, wytrzymałości na rozciąganie i badanie nasiąkliwości. Wykazano, że dla pianobetonu wraz ze wzrostem gęstości wrasta wytrzymałość na ściskanie, wytrzymałość na rozciąganie, natomiast spada nasiąkliwość materiału. Ponadto wykonano także badanie mrozoodporności, gdzie próbki pianobetonu zostały poddane 25 cyklom zamrażaniaodmrażania. Zaobserwowano $15 \%$ spadek wytrzymałości na ściskanie próbek poddanych cyklom zamrażania-odmrażania w porównaniu do próbek nie poddanych działaniu mrozu (świadków). Wyniki analiz numerycznych wskazują, że w spodzie warstwy podbudowy pomocniczej z materiałów stabilizowanych spoiwami hydraulicznymi dla nawierzchni kategorii ruchu KR5 ułożonej na podłożu o nośności $\mathrm{G} 1 \div \mathrm{G} 4$, powstają naprężenia rozciągające niższe niż wytrzymałość na rozciąganie dla pianobetonów o gęstości $860 \div 1060 \mathrm{~kg} / \mathrm{m}^{3}$.
\end{abstract}

Słowa kluczowe: beton lekki, metody mechanistyczne, metody numeryczne, MES

\footnotetext{
${ }^{1}$ Marta Kadela, Instytut Techniki Budowlanej, 00-611 Warszawa, ul. Filtrowa 1, +48 327302948 , m.kadela@itb.pl
} 


\section{Wstęp}

\subsection{Uwagi ogólne}

Pianobeton klasyfikuje się jako beton lekki o większej niż $20 \%$ objętości porów w zaczynie cementowym, wytworzonych przy zastosowaniu odpowiedniego środka pianotwórczego [33]. Materiał ten charakteryzuje się specyficznymi cechami takimi jak: dobra płynność, samozagęszczalność, samopoziomowanie, stabilność wymiarowa i przede wszystkim mała gęstość, a jego skład może tak być projektowany, by materiał wykazywał małą wytrzymałość, dobre właściwości termoizolacyjne, dobrą nośność przy relatywnie małej gęstości. To właśnie możliwość uzyskania szerokiego zakresu gęstości, wbudowywania go w formie ciekłej oraz łatwy proces wytwarzania produkcji są głównymi walorami pianobetonu, pozwalającymi na jego zastosowanie w różnych specyficznych rozwiązaniach [6, 10, 27]. W drogownictwie szczególnie docenia się łatwość jego wbudowania i usunięcia np. przy przebudowie.

W budownictwie komunikacyjnym może być stosowany jako materiał niekonstrukcyjny (wypełniający, pomocniczy) lub jako materiał konstrukcyjny, wbudowany w warstwy nawierzchni drogowej. Osobną ścieżkę stanowi zastosowanie pianobetonu w komunikacyjnych obiektach mostowych, w tunelach, przepustach itp. [2,3], czy w posadowieniu obiektów towarzyszących, np. stacji benzynowej [28].
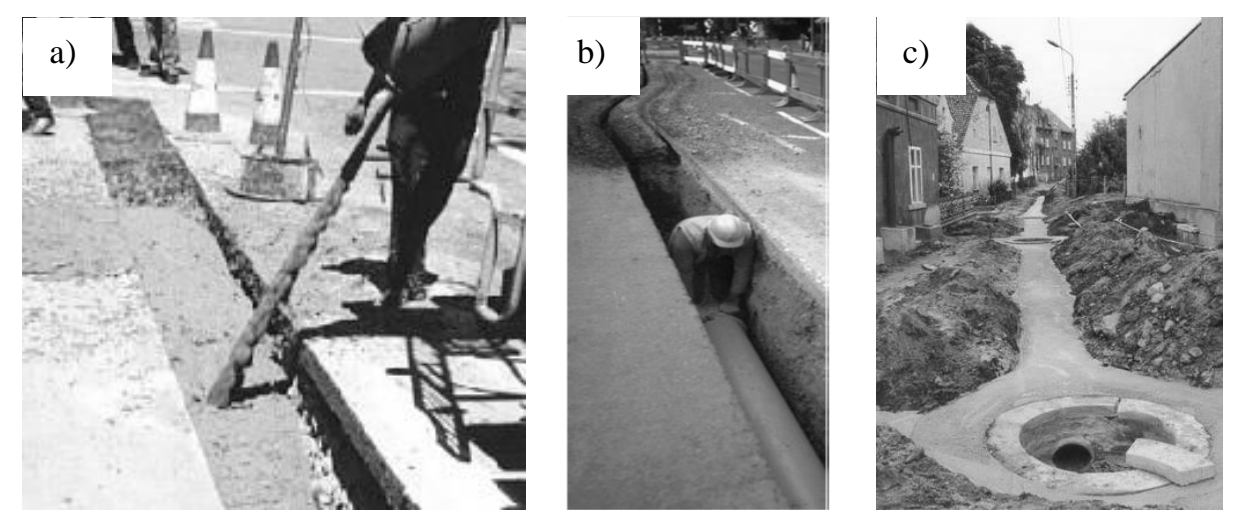

Rys. 1. Pianobeton jako materiał wypełniający, na podstawie [1, 30, 31]

Fig. 1. Foamed concrete as material to filling backfill, based on [1, 30, 31]

Jako materiał wypełniający może być zastosowany przy wypełnieniu pustych przestrzeni (rys. 1a) lub przy robotach związanych $z$ wykonaniem infrastruktury technicznej w obrębie drogi np. przy wypełnieniu starych rur kanalizacyjnych, przestrzeni międzyrurowej instalacji wodnych i kanalizacyjnych (rys. 1b), czy przestrzeni przy studzienkach kanalizacyjnych (rys. 1c). Często 
stosuje się go przy robotach remontowych infrastruktury technicznej, gdyż dzięki łatwemu wykonaniu, skrócony zostaje czas wykonywania robót, a tym samym wyłączenia drogi z ruchu.

W Polsce rozwiązanie takie zostało zastosowane w Głogowie, gdzie płytkie wykopy pod nowo położoną sieć kanalizacyjną (o głębokości $0,4 \div 0,6 \mathrm{~m}$ pod nawierzchnią drogi) zostały wypełnione pianobetonem, bezpośrednio na którym ułożona została nawierzchnia drogi [1].

Docenienie zalet pianobetonu związanych $\mathrm{z}$ jego łatwym wbudowywaniem oraz małą gęstością można dostrzec $\mathrm{w}$ wielu konstrukcjach nawierzchni, między innymi przy rekonstrukcji i przebudowie nawierzchni drogowych, przy poszerzaniu pasów jezdni, tworzeniu miejsc postojowych, czy drogach na słabym podłożu $[3,4,9,23]$.

Jednym z takich projektów jest rekonstrukcja nawierzchni drogi Cypres Avenue w stanie Oakland w USA po rozległych szkodach w skutek trzęsienia ziemi w $1989 \mathrm{r}$. Warstwa z pianobetonu o gęstości $500 \mathrm{~kg} / \mathrm{m}^{3}$ i wytrzymałości 1,0 MPa została wykonana w celu zmniejszenia wpływu oddziaływania przekazywanego z podłoża i zmniejszenia w ten sposób szkód spowodowanych wstrząsem sejsmicznym w przyszłości [3]. Pianobeton został wykorzystany także przy przebudowie czteropasmowej autostrady The Central Road (rys. 2.) w Schaumburg w stanie Illinois (USA). Wykonano wówczas lekkie wypełnienie z dwóch warstw z pianobetonu (pierwsza o gęstości $400 \mathrm{~kg} / \mathrm{m}^{3}$ i grubości $0,9 \mathrm{~m}$, a druga - o gęstości $500 \mathrm{~kg} / \mathrm{m}^{3}$ i grubości $0,43 \mathrm{~m}$ ) na odcinku o długości przekraczającej $3 \mathrm{~km}$ i na pełnej szerokości drogi. Rozwiązanie takie zostało zaproponowane $\mathrm{z}$ uwagi na panujące warunki gruntowe - tereny bagienne z położonymi, na głębokości $3 \div 5 \mathrm{~m}$ pod powierzchnią, miękkoplastycznymi gruntami organicznymi (torfem).

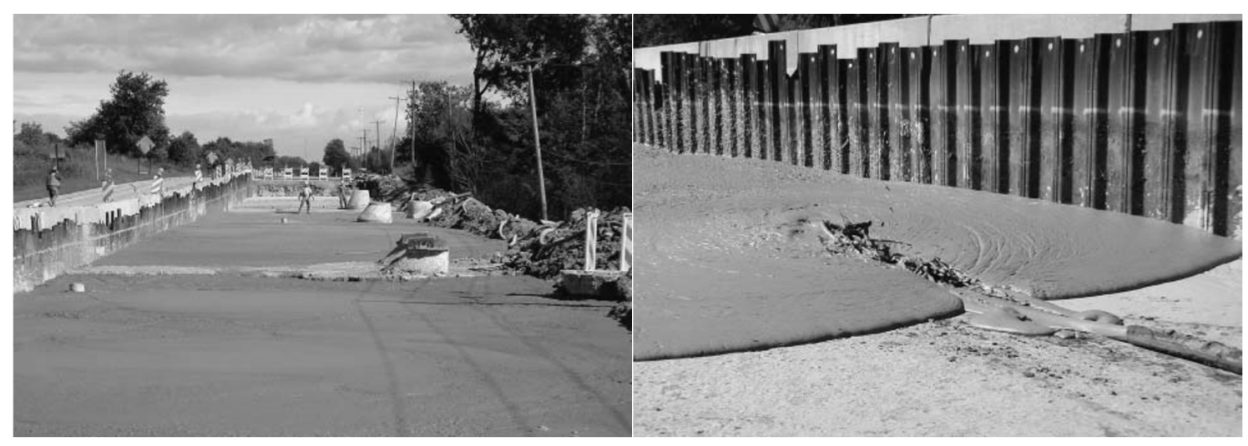

Rys. 2. Zastosowanie pianobetonu przy przebudowie Central Road, na podstawie [32]

Fig. 2. An application of foamed concrete during the reconstruction of Central Road, based on [32] 
W Wielkiej Brytanii pianobeton po raz pierwszy został zastosowany w nawierzchni autostrady w 1970 r. Jako materiał budowlany, konkurencyjny do powszechnie stosowanych, został jednak uznany dopiero po około 10 latach. Przykładem jego zastosowania może być wbudowanie pianobetonu o gęstości $500 \mathrm{~kg} / \mathrm{m}^{3}$ w nawierzchnie dwóch dróg dojazdowych do kompleksu biurowego Canary Wharf w dzielnicy Londynu Docklands [3]. Innym przykładem jest wykorzystanie pianobetonu jako materiału bazowego do wykonania dróg, w nowo wybudowanej strefie przemysłowej Hertfordshire (UK). Rozwiązanie to przyjęto, $\mathrm{z}$ uwagi na zalegające w podłożu gruntowym torfy, które w połączeniu z wysokim poziomem wód gruntowych, przyczyniły się do powstania licznych podtopień [29].

W Polsce pianobeton został użyty jako podbudowa pod nawierzchnię z kostki betonowej, np. przy parkingu salonu meblowego firmy Baxpol w Toruniu [24].

Projektowanie dróg publicznych wszystkich klas odbywa się, bazując na katalogu [11] lub stosując indywidualne projektowanie przy użyciu metod mechanistycznych opierających się na kryteriach zmęczeniowych. Zgodnie z niniejszym katalogiem $\mathrm{w}$ warstwę podbudowy pomocniczej nawierzchni dla kategorii ruchu KR5 $\div$ KR7 może być wbudowany beton C5/6 o wytrzymałości na ściskanie $f_{c} \leq 10 \mathrm{MPa}$. Oszacowano na podstawie rys. 6, że wymaganie takie spełnia także pianobeton o gęstości w zakresie $860 \div 1060 \mathrm{~kg} / \mathrm{m}^{3}$. Dlatego celem sprawdzenia możliwości wbudowania nowego materiału - pianobetonu w dolne warstwy konstrukcji nawierzchni (podbudowę pomocniczą) zostały przeprowadzone analizy numeryczne układu nawierzchnia drogowawzmocnione podłoże gruntowe. Jednakże wprowadzenie do powszechnego stosowania pianobetonu w kontakcie z podłożem gruntowym wymaga oprócz spełnienia określonych wymagań, także zapewnienia dla tego wyrobu odpowiednich właściwości materiałowych i mechanicznych, związanych z występującymi na danym terenie uwarunkowaniami gruntowo-wodnymi oraz czynnikami zewnętrznymi, na które będzie narażony (temperatura, wilgoć, a przede wszystkim prognozowane obciążenie).

\section{Charakterystyka materiałowa pianobetonu}

Pianobeton jest to materiał, w skład którego wchodzi cement portlandzki 42,5R, woda i środek pianotwórczy w ilości $2 \div 10$ 1/100 kg cementu w zależności od pożądanej gęstości materiału [20]. Na podstawie doświadczeń przyjęto wskaźnik wodno-cementowy $w / c=0,44$.

W Polsce jedynym wymaganiem dla zastosowania materiału związanego spoiwami hydraulicznymi w konstrukcji nawierzchni jest wytrzymałość na ściskanie $f_{c}$, podczas gdy w niektórych krajach dodatkowo wymaga się odpowiedniej wytrzymałości na rozciąganie. Z uwagi na naprężenia rozciągające $\mathrm{w}$ spodzie warstwy oraz możliwość ewentualnego pękania [17, 21, 22], testy takie, chcąc zastosować nowy materiał w konstrukcji nawierzchni, wydają się być szczególnie zasadne. 
Badania wytrzymałości na rozciąganie $f_{t k}$ dla pianobetonu o różnej gęstości zostały przeprowadzone na belkach o wymiarach $100 \times 100 \times 500 \mathrm{~mm}$ zgodnie z normą PN-EN 12390-5:2011. Nominalna odległość pomiędzy podporami wynosiła $300 \mathrm{~mm}$. Obciążenie przykładane w połowie szerokości belki było zadawane ze stałą prędkością przemieszczania $0,1 \mathrm{~mm} / \mathrm{min}$. Wartość ta została dobrana empirycznie. Na podstawie otrzymanych danych (rys. 3.) wyznaczono dla pianobetonu o gęstości w zakresie $860 \div 1060 \mathrm{~kg} / \mathrm{m}^{3}$ wytrzymałość na rozciąganie równą $0,55 \div 0,67 \mathrm{MPa}$.

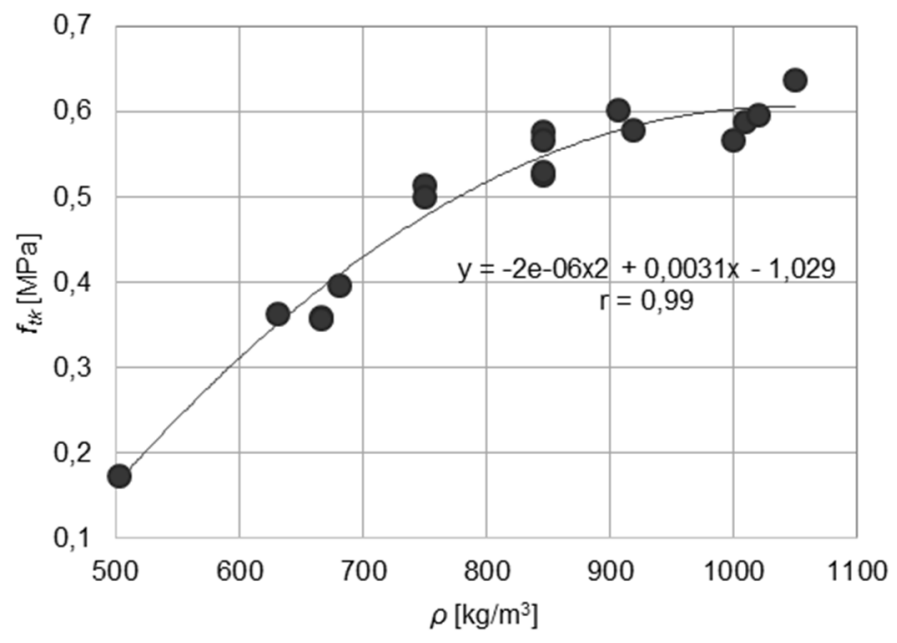

Rys. 3. Wyniki wytrzymałości na rozciąganie w zależności od gęstości pianobetonu

Fig. 3. Results of flexural strength depending on density of foamed concrete

$\mathrm{Z}$ uwagi na potencjalne zastosowanie materiału $\mathrm{w}$ warunkach zewnętrznych, w kontakcie $\mathrm{z}$ podłożem gruntowym, przeprowadzono dodatkowe badania mrozoodporności i nasiąkliwości.

Pianobeton jest stosunkowo nowym materiałem, dla którego nie ma w chwili obecnej znormalizowanych metod badawczych pozwalających na określenie tych właściwości, dlatego badania przeprowadzono na podstawie dostępnej literatury przedmiotu, doświadczenia badawczego laborantów oraz mając na uwadze uwzględnienie $\mathrm{m}$. in. porowatości próbek, ich masy, możliwości występowania skurczu podczas suszenia próbek, a także rzeczywistych warunków związanych z planowanym zastosowaniem badanego materiału. Opis badań przedstawiono w pracy [19]. Z wcześniejszych badań Kadeli i in. $[19,20]$ wynika, że istnieje statystycznie istotna zależność między gęstością pianobetonu a jego wytrzymałością na ściskanie (rys. 4.) i nasiąkliwością (rys. 5.). Wykazano także, że pianobeton bez względu na swoją gęstość nie ulega korozji mrozowej (rys. 4.). 


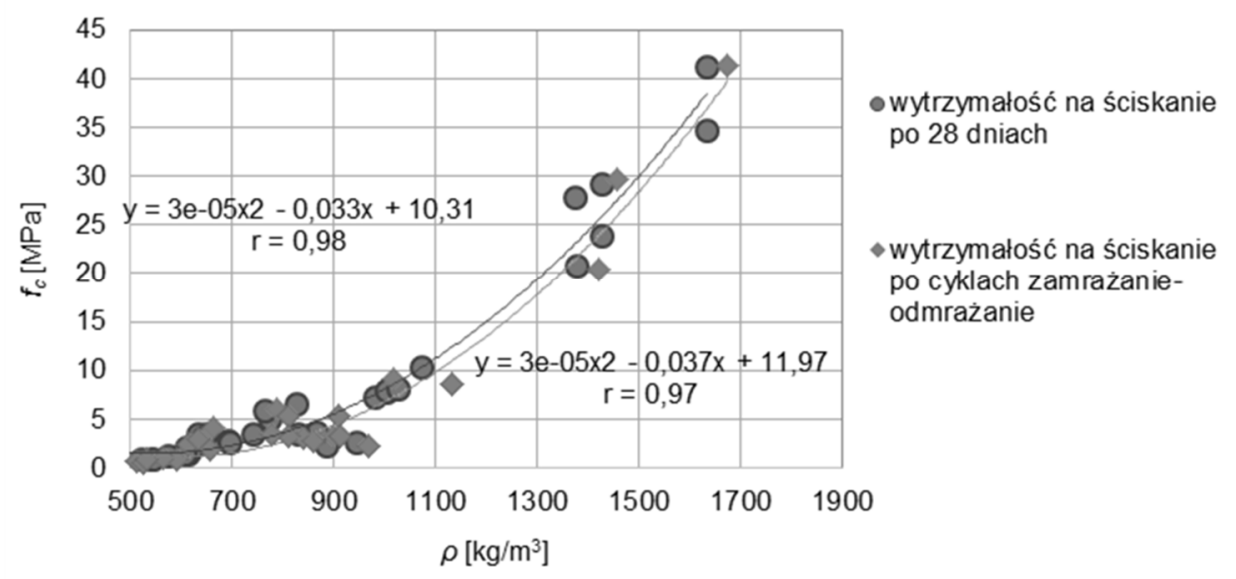

Rys. 4. Wyniki wytrzymałości na ściskanie w zależności od gęstości pianobetonu

Fig. 4. Results of compressive strength depending on density of foamed concrete

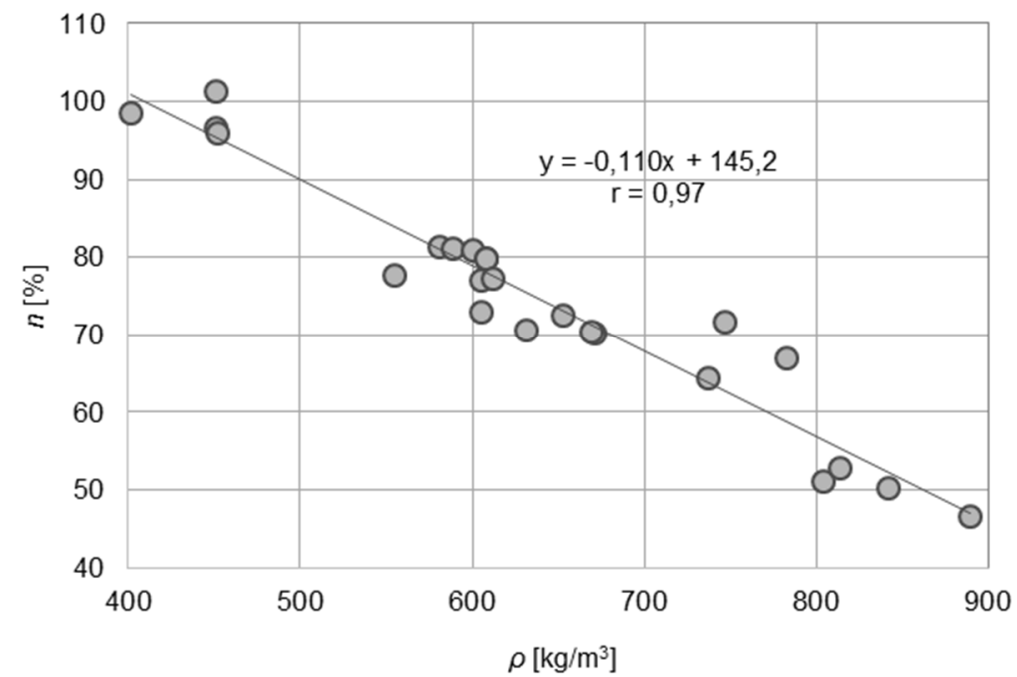

Rys. 5. Wyniki nasiąkliwości w zależności od gęstości pianobetonu

Fig. 5. Results of absorption of water depending on density of foamed concrete

Celem oceny zachowania się materiału w rzeczywistych warunkach temperaturowo-wilgotnościowych $\mathrm{w}$ dłuższym okresie czasu wylane zostały $\mathrm{w}$ dniu 11.08.2014 r. cztery płyty z pianobetonu o różnym składzie (rys. 6.). W trakcie prowadzonych przez około trzy lata obserwacji nie zauważono zmian na powierzchni płyt na skutek oddziaływania czynników zewnętrznych. 


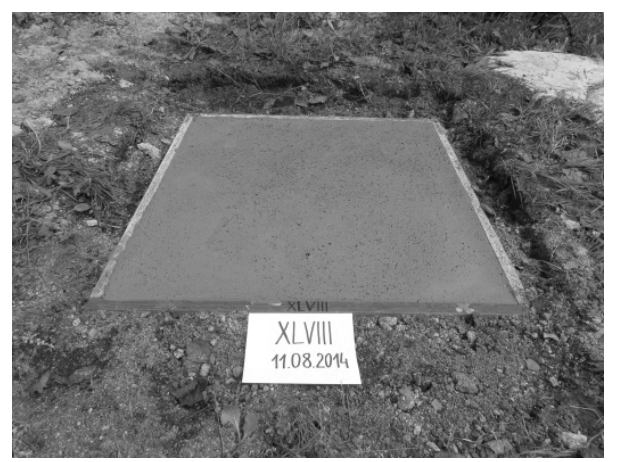

Rys. 6. Przykładowa płyta z pianobetonu

Fig. 6. An example slab of foamed concrete

\section{Model obliczeniowy}

Do analizy możliwości zastosowania pianobetonu w warstwie konstrukcji nawierzchni wykorzystano metody mechanistyczne. Są to metody projektowania teoretyczno-empiryczne, obejmujące analizę konstrukcji nawierzchni opartą o analizę stanu naprężenia i odkształcenia oraz dodatkowo o wyniki badań eksperymentalnych. Stan naprężenia i odkształcenia wyznacza się w przyjętym modelu obliczeniowym układu nawierzchnia drogowa-podłoże gruntowe. W niniejszej pracy posłużono się modelem obliczeniowym układu nawierzchnia drogowapodłoże gruntowe $\mathrm{z}$ wykorzystaniem powszechnie dostępnego oprogramowania MES, w tym celu wykorzystano program ZSoil.PC. Narzędzie, jakim jest numeryczny model obliczeniowy, może być w pewnym stopniu niejednoznaczne, ponieważ ogólnie model tworzony jest w różny sposób [14]. Przykładem mogą być prace $[5,7,8,16,18,25,26]$. Na istotę powstałych różnic mają wpływ głównie:

1) budowa geometryczna modelu obliczeniowego oraz sposób wprowadzania warunków brzegowych,

2) przyjęcie modeli konstytutywnych materiałów warstw konstrukcji oraz modelu podłoża gruntowego, wraz z doborem adekwatnych parametrów modeli,

3) sposób realizacji obciążenia w modelach obliczeniowych (2D) lub (3D) [12].

Na potrzeby niniejszego artykułu do obliczeń wykorzystano model obliczeniowy układu nawierzchnia drogowa-podłoże wzmocnione w stanie osiowej symetrii. Do obliczeń przyjęto nawierzchnię typu podatnego A1, dla kategorii ruchu KR5 (układ warstw $1 \div 4$ na rys. 7.). Przedmiotem rozważań było podłoże wzmocnione, gdzie w celu doprowadzenia do odpowiedniej nośności podłoża w dolną warstwę konstrukcji nawierzchni (warstwę podbudowy pomocniczej oznaczonej cyfrą 5 na rys. 7.) została wbudowana mieszanka związana spoiwem hydraulicznym (typ 2 według Katalogu [11]). Rozwiązanie takie zostało wybrane jako reprezentatywne dla możliwości zastosowania pianobetonu. 


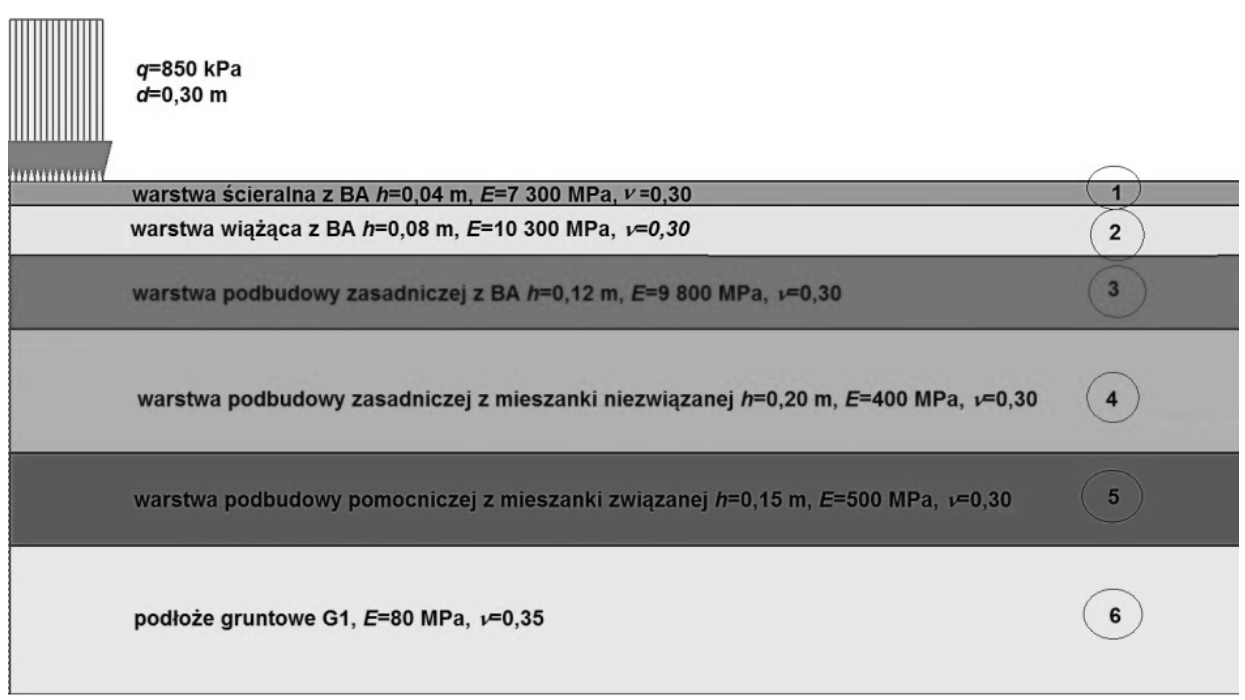

Rys. 7. Przyjęty układ nawierzchnia-podłoże wzmocnione; nawierzchnia typu A1

Fig. 7. An assumed pavement structure-subgrade system; type A1 pavement structure

Wymiary modelu obliczeniowego MES (rys. 8.) zostały dobrane zgodnie z założeniami opracowanymi w pracy [15]. Przyjęto obciążenie równomiernie rozłożone $q=850 \mathrm{kPa}$, co odpowiada obciążeniu osi obliczeniowej pojazdu $P=100 \mathrm{kN}$ (50 kN na koło). Warstwy nawierzchni i podłoże gruntowe przyjęto jako jednorodne, izotropowe. Poszczególne podukłady zostały opisane związkami liniowej sprężystości. Przyjęto warunki pełnej sczepności pomiędzy warstwami. Model MES został zdyskretyzowany siatką o wymiarach boków równych $10 \mathrm{~mm}$ w strefie zagęszczenia pod obciążeniem, a wymiary boków elementów siatki w pozostałym dyskretyzowanym obszarze zostały tak dobrane, by zachować proporcję 1:3 [13]. 


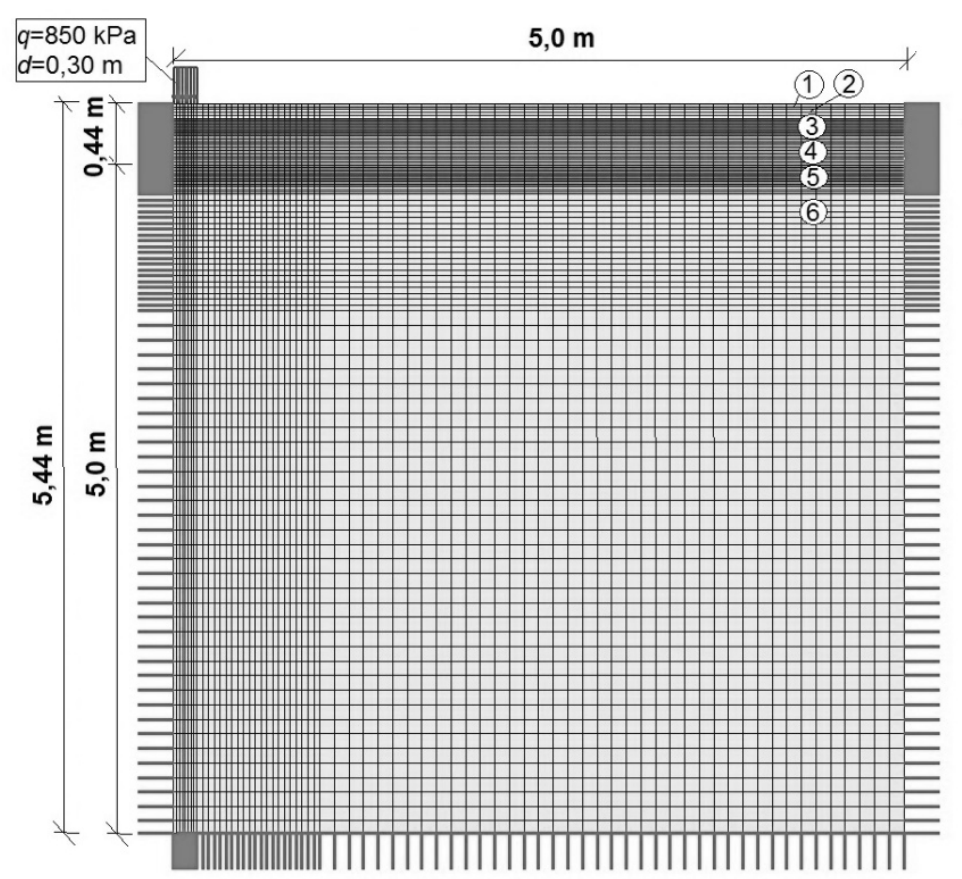

Rys. 8. Model MES układu nawierzchnia-podłoże wzmocnione; nawierzchnia typu A1

Fig. 8. Finite element model of pavement structure-subgrade system; type A1 pavement structure

\section{Wyniki}

Rozkład naprężenia poziomego wyznaczony na podstawie przeprowadzonych analiz numerycznych układu obliczeniowego nawierzchnia-podłoże wzmocnione został przedstawiony na rys. 9. Maksymalne naprężenie rozciągające w spodzie warstwy związanej spoiwami hydraulicznymi (warstwa na rys. 9.) wynosi 39,34 $\mathrm{kPa}$.

Analizy powtórzono dla podłoża gruntowego o wtórnym module odkształcenia równym 50, 35 i $25 \mathrm{MPa}$, co odpowiada grupom nośności podłoża (G2, G3 i G4), przyjmując każdorazowo odpowiadający tej grupie zgodnie z Katalogiem [11] układ warstw wzmocnionych (tab. 1). W wyniku przeprowadzonych analiz numerycznych dla wszystkich typowych rozwiązań dolnych warstw konstrukcji nawierzchni i warstwy ulepszonego podłoża, otrzymano bardzo zbliżone wartości naprężenia rozciągającego w spodzie warstwy stabilizowanej spoiwem hydraulicznym $\sigma_{x \dot{s} r}=39,0 \pm 0,5 \mathrm{kPa}$. Jako wartość reprezentatywną przyjęto największą otrzymaną wartość $\sigma_{x \max }=39,5 \mathrm{kPa} \approx 0,40 \mathrm{MPa}$. 


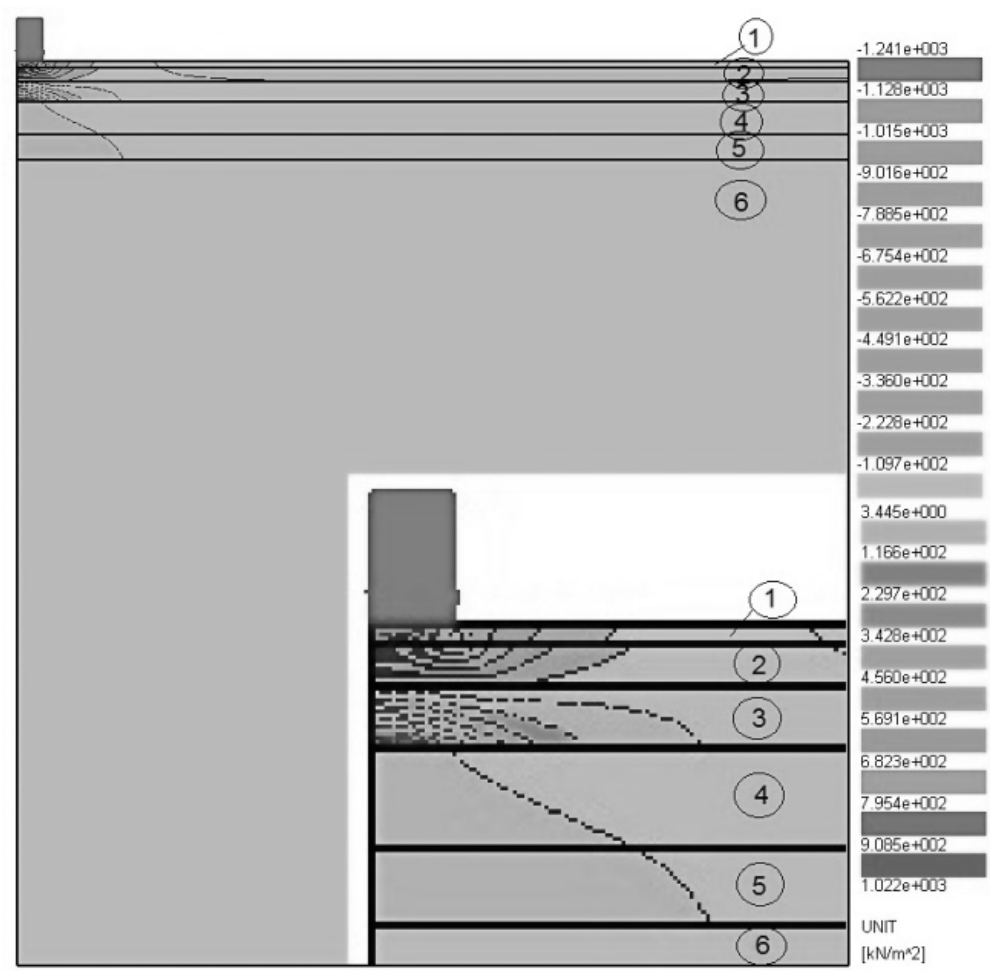

Rys. 9. Mapa naprężeń rozciągających

Fig. 9. Maps of flexural stress

Tabela 1. Typowe rozwiązania dolnych warstw konstrukcji nawierzchni i warstwy ulepszonego podłoża w przypadku kategorii ruchu KR5 $\div$ KR7 dla typu 2 według [11]

Table 1. Typical scheme of bottom layers of pavement and reinforced layer of subsoil for KR $\div \div \mathrm{KR} 7$ traffic category according to [11]

\begin{tabular}{|l|c|c|c|c|}
\hline Grupa nośności podłoża & G1 & G2 & G3 & G4 \\
\hline $\begin{array}{l}\text { Wtórny moduł odkształcenia } \\
E_{0}[\mathrm{MPa}]\end{array}$ & 80 & 50 & 35 & 25 \\
\hline $\begin{array}{l}\text { Układ dolnych warstw kon- } \\
\text { strukcji i warstwy ulepszone- } \\
\text { go podłoża }\end{array}$ & 15 & $\begin{array}{l}20 \\
\text { - dolna warstwa konstrukcji nawierzchni z mieszanki związanej spoiwem hy- } \\
\text { draulicznym }\end{array}$ \\
\hline $\begin{array}{l}\text { - warstwa ulepszonego podłoża z mieszanki niezwiązanej lub z gruntu niewysa- } \\
\text { dzinowego (naturalnego lub antropogenicznego) o CBR } \geq 20 \% \text {; o ile to konieczne } \\
\text { warstwa ulepszonego podłoża pełni funkcję warstwy odsączającej o } k \geq 8 \mathrm{~m} / \text { dobę }\end{array}$ \\
\hline
\end{tabular}


Otrzymane wartości naprężeń rozciągających w spodzie warstwy podbudowy pomocniczej są znacznie mniejsze niż wyznaczone w badaniach laboratoryjnych wartości wytrzymałości na rozciąganie dla pianobetonów o gęstości większej niż $680 \mathrm{~kg} / \mathrm{m}^{3}$ (rys. 3.). Próby w skali półtechnicznej potwierdzają zatem możliwość zastosowania pianobetonu jako warstwy podbudowy pomocniczej. Poprawność tego rozwiązania zostanie również oceniona w warunkach in situ na poligonie badawczym.

\section{Podsumowanie}

Obecnie obserwuje się rosnące zainteresowanie pianobetonem zarówno w literaturze przedmiotu (pod względem oceny wpływu poszczególnych składników na właściwości materiału, oceniane laboratoryjnie) oraz w inwestycjach, przede wszystkim zagranicznych. Jest to związane z licznymi zaletami materiału, jest to przede wszystkim materiał o możliwości osiągnięcia szerokiego zakresu jego właściwości, samopoziomujący się oraz samozagęszczalny. Dodatkowo możliwość jego zabudowany w postaci płynnej pozwala na jego zastosowanie w różnych aplikacjach. W budownictwie komunikacyjnym może być stosowany jako materiał wypełniający przede wszystkim przestrzenie przy robotach związanych z infrastrukturą techniczną lub jako materiał konstrukcyjny, stanowiący warstwę nawierzchni drogowej. Przeprowadzone badania laboratoryjne pokazują, że pianobeton o gęstości w zakresie $860 \div 1060 \mathrm{~kg} / \mathrm{m}^{3}$ spełnia wymagania Katalogu [11] dla materiału podbudowy pomocniczej z mieszanki związanej spoiwem hydraulicznym. Również przeprowadzone analizy numeryczne układu nawierzchnia drogowa-podłoże gruntowe wskazują, że w spodzie podbudowy pomocniczej stabilizowanej spoiwem hydraulicznym powstaną naprężenia rozciągające mniejsze niż wytrzymałość na rozciąganie dla pianobetonów o gęstości większej niż $680 \mathrm{~kg} / \mathrm{m}^{3}$. Powyższe stanowi dobrą przesłankę do wprowadzenia tego materiału do powszechnego stosowania w konstrukcji nawierzchni drogowej.

\section{Podziękowania}

Przedstawione $w$ niniejszym artykule wyniki sq częścia badań prowadzonych $w$ ramach projektu badawczego "Wzmacnianie stabego podtoża poprzez zastosowanie warstwy z pianobetonu $w$ kontakcie z podtożem gruntowym" (LIDER/022/537/L-4/NCBR/2013), finansowanego przez Narodowe Centrum Badań i Rozwoju w ramach programu LIDER IV.

\section{Literatura}

[1] Chady A.: Zastosowanie pianobetonu przy realizacji systemów komunalnych, 2007, http://www.muratorplus.pl/technika/kanalizacja-i-odwodnienia/zastosowanie-pianobetonuprzy-realizacji-systemow-komunalnych_57589.html?\&page=0 (dostęp: 22 lutego 2017 r.). 
[2] Decký M., Drusa M., Zgútová K., Braško M., Hájek M., Scherfel W.: Foam Concrete as New Material in Road Constructions. Procedia Engineering, Proceeding of WMCAUS 2016, vol. 161, 2016, pp. 428-433, DOI: 10.1016/j.proeng.2016.08.585.

[3] Dhir R.K., Newlands M.D., McCarthy A.: Use of Foamed Construction, Thomas Telford, Londyn 2005.

[4] Drusa M., Fedorowicz L., Kadela M., Scherfel W.: Application of geotechnical models in the description of composite foamed concrete used in contact layer with the subsoil, Proceedings on CD of the 10th Slovak Geotechnical Conference "Geotechnical problems of engineering constructions", Slovak University of Technology, Bratislava 2011.

[5] Fedorowicz L., Fedorowicz J., Kadela M.: Problemy właściwej interpretacji wyników analiz układów konstrukcja-podłoże gruntowe, Górnictwo i Geoinżynieria Kwartalnik AGH, nr 35(2), 2011, s. 209-216.

[6] Fedorowicz L., Kadela M.: Foamed concrete used a subbase for some systems structuresubsoil, Proceedings on CD of the 7th congress ENGINEERING GEOLOGY 2012, Slovak University of Technology, Bratislava 2012.

[7] Fedorowicz L., Kadela, M.: Model calibration of line construction-subsoil assisted by experimental research, AGH Journal of Mining and Geoengineering, vol. 36, 2012, pp. 155-164.

[8] Fedorowicz L., Kadela M.: Modelowanie numeryczne odkształceń nawierzchni drogowej w świetle wyników monitoringu na przykładzie drogi dojazdowej do kompleksu hal logistycznych, Przegląd Komunikacyjny, nr 9, 2012, s. 22-27.

[9] Fedorowicz L., Kadela M., Bednarski Ł.: Modelowanie zachowania pianobetonu w konstrukcjach warstwowych współpracujących z podłożem gruntowym, Zeszyty Naukowe WST, nr 6, 2014, s. 73-81.

[10] Jones M.R., McCarthy A.: Preliminary views on the potential of foamed concrete as a structural material, Magazine of Concrete Research, vol. 57, 2005, pp. 21-31.

[11] Judycki J. (red.): Katalog typowych konstrukcji nawierzchni podatnych i półsztywnych, GDDKiA, Wydawnictwo Politechniki Gdańskiej, Gdańsk 2012.

[12] Kadela M.: Kryteria modelowania i analiz konstrukcji warstwowej współpracującej z podłożem gruntowym, Praca doktorska, Politechnika Śląska, Gliwice 2012.

[13] Kadela M.: Model of multiple-layer pavement structure-subsoil system. Bulletin of The Polish Academy of Science, Technical Sciences, vol. 64, no. 4, 2016, pp. 751-762, DOI: 10.1515/bpasts-2016-0084.

[14] Kadela M.: Problemy budowy wiarygodnego modelu konstrukcja drogowa - podłoże gruntowe, Praca zbiorowa pod red. A Wawrzynka ,Wybrane zagadnienia z dziedziny budownictwa”, Wydawnictwo Politechniki Śląskiej, Gliwice 2009, s. 433-442.

[15] Kadela M.: Układy nawierzchnia drogowa-podłoże gruntowe w modelach numerycznych i badaniach in situ. Wydawnictwo Politechniki Śląskiej, Gliwice 2016.

[16] Kadela M.: Zastosowanie prostych modeli numerycznych podłoża gruntowego do opisu pracy współpracującej z nim konstrukcji warstwowej, Czasopismo Naukowe „Nauka Przyroda Technologie”, Tom 6, Zeszyt 2, Wydawnictwo Uniwersytetu Przyrodniczego w Poznaniu, 2012. 
[17] Kadela M., Cińcio A., Kozłowski M.: Degradation analysis of notched foam concrete beam, Applied Mechanics and Materials, vol. 797, 2015, pp. 96-100, DOI: 10.4028/www.scientific.net/AMM.797.96.

[18] Kadela M., Fedorowicz L.: Model obliczeniowy układu konstrukcja warstwowa-podłoże gruntowe zgodnie z EC7, ACTA Scientiarum Polonorum ARCHITECTURA, nr 12(3), 2013, s. 17-25.

[19] Kadela M., Kukiełka A., Winkler-Skalna A.: Ocena nasiąkliwości i mrozoodporności pianobetonu, Materiały budowlane, nr 530(10), 2016, s. 50-51, DOI: 10.15199/33.2016.10.16.

[20] Kadela M., Winkler-Skalna A., Łoboda B., Kukiełka A.: PIANOBETON - charakterystyka materiałowa oraz możliwości zastosowania. Materiały budowlane, nr 7, 2005, s. 108-110, DOI: 10.15199/33.2015.07.30.

[21] Kozłowski M., Kadela M., Gwóźdź-Lasoń M.: Numerical fracture analysis of foamed concrete beam using XFEM method, Applied Mechanics and Materials, vol. 837, 2016, pp. 183-186, DOI: 10.4028/www.scientific.net/AMM.837.183.

[22] Kozłowki M., Kadela M., Kukiełka A.: Fracture energy of foamed concrete based on three-point bending test on notched beams. Procedia Engineering, Proceeding of 7th Scientific-Technical Conference on Material Problems in Civil Engineering MATBUD'2015, vol. 108, 2015, pp. 349-354, DOI: 10.1016/j.proeng.2015.06.157.

[23] Lee Y.L., Goh K.S., Koh H.B., Ismail B.: Foamed aggregate pervious concrete an option for road on peat, Proceedings of MUCEET 2009, Malaysian Technical Universities Conference on Engineering and Technology, Kuantan, Pahang 2009.

[24] LiderBudowlany: Pianobeton - zastosowanie. Beton komórkowy do badań zwykłych i specjalnych, 2014, http://www.liderbudowlany.pl/artykul/252/pianobetonzastosowania (dostęp: 22 lutego 2017 r.).

[25] Maina J.W., Ozawa Y., Matsui K.: Linear elastic analysis of pavement structure under non-circular loading, Road Materials and Pavement Design, vol. 13(3), 2012, pp. 403-421.

[26] Nagórski R.: Mechanika nawierzchni drogowych w zarysie, PWN, Warszawa 2014.

[27] Ramamurthy R., Kunhanandan Nambiar E.K., Indu Siva Ranjani G.: A classification of studies on properties of foam concrete, Cement and Concrete Composites, vol. 31(6), 2009, pp. 388-396, DOI: 10.1016/j.cemconcomp.2009.04.006.

[28] Stilger-Szydło E.: Posadowienie budowli infrastruktur transportu lądowego. Teoria Projektowanie - Realizacja, Dolnośląskie Wydawnictwo Edukacyjne, Wrocław 2005.

[29] Tian W., Li L., Zhao X., Zhou M., Wamg N.: Application of foamed concrete in road engineering. ICTE 2009, 2009.

[30] www.cemex.co.uk.

[31] www.eabassoc.co.uk.

[32] www.provoton.com.

[33] Van Deijk S.: Foamed Concrete - A Dutch View. BCA, Camberley 1992. 


\section{APPLICATION OF FOAMED CONCRETE IN LAYERS OF PAVEMENT STRUCTURE}

\section{S u m m a r y}

Foamed concrete is classified as a lightweight concrete. It is a cement mortar in which airvoids are entrapped by foaming agent. Although foamed concrete is known for about 100 years, its practical application is mainly limited to non-structural material. For many years, the application of foamed concrete has been limited to backfill of retaining walls, insulation of foundations, roof tiles and sound insulation. However, in the last few years foamed concrete has become a promising material also for structural purposes. The paper presents the use of foamed concrete in road construction, with particular emphasis on road pavements.

The results of laboratory tests and numerical analyzes are also presented. Series of tests was carried out to examine the physical parameters of foamed concrete: compressive strength, flexural strength and absorption of water. The compressive strength and flexural strength decreased with the decrease of the density of the foamed concrete, while the water absorption increased. Furthermore, the influence of 25 cycles of freezing and thawing on the compressive strength was examined. The compressive strength of foamed concrete subjected to freeze-thaw tests was only approx. $15 \%$ lower comparing to untreated specimens.

The results of numerical simulations show that the maximal tensile stress in the lower zone of subbase layer, for the pavement structure KR5 and subgrade types G1 $\div \mathrm{G} 4$, is lower than the flexural strength of foamed concrete with the density of $860 \div 1060 \mathrm{~kg} / \mathrm{m}^{3}$ determined in laboratory tests. It shows potential possibility of using foamed concrete layer as a subbase for pavement structures.

Keywords: lightweight concrete, mechanistic methods, numerical analysis, FEM

Przestano do redakcji: 01.06.2017 r.

Przyjęto do druku: 01.09

$.2017 \mathrm{r}$. 